\title{
INSTITUTIONS IN PROVIDING LEGAL AID FOR SUSPECTS AND DEFENDANTS
}

\author{
Syalis Mei Setiani \\ Center of Clinical Legal Education, Universitas Negeri Semarang, Indonesia \\ *Email: syalismei@gmail.com
}

Indonesia is a state of law, one of which is equality before the law. One of the forms is the existence of legal aid institutions to protect human rights. In this case, it is the suspect/defendant whose rights are often violated due to the arbitrariness of the legal apparatus from arrest to trial. Even though legal rules and codes of ethics have been regulated, every law enforcement officer cannot guarantee that the rights of the community, especially suspects and defendants, are fulfilled. So that this legal aid institution takes the role so that people's rights, both legal protection, legal assistance, good treatment can be accepted by suspects or defendants, so that arbitrariness does not occur. For this reason, legal aid institutions recruit advocates, paralegals, lecturers, and law students to participate in implementing legal aid. Legal aid is given to the poor but does not rule out the possibility of giving it to children, persons with disabilities, women, the elderly, Indonesian workers, or other vulnerable people or groups in accordance with their regional context and regulated in laws and regulations. The suspect himself must be given to the suspect who is threatened with imprisonment of more than 5 years and is incapacitated or is threatened with a sentence of 15 years or death.

The Indonesian Journal of International Clinical Legal Education DOI: https://doi.org/10.15294/ijicle.v3i4.48297

Submitted: Dec 12, 2020 Revised: March 13, 2021 Accepted: August 10, 2021 Available online at https://journal.unnes.ac.id/sju/index.php/iccle (c) 2021 Authors. This work is licensed under a Creative Commons AttributionShareAlike 4.0 International License (CC BY-SA 4.0). All writings published in this journal are personal views of the authors and do not represent the views of this journal and the author's affiliated institutions. 
Otherwise, the claim is considered invalid. However, suspects with criminal penalties under 5 years are also entitled to such legal assistance. To carry out this protection, all roles related to legal aid, both legal aid institutions, law enforcement officers, central government, local governments, and the community who are given legal assistance are very important in their involvement to succeed in legal protection and equality before the law.

Keywords: Legal Aid; Legal Protection; Criminal Justise System

\section{INTRODUCTION}

Indonesia is a state of law as stated in Article 1 paragraph (3) of the 1945 Constitution. In a state of law, the principles of the rule of law include, among others, the rule of law, equality before the law, and law enforcement in ways that do not conflict with the law. One of the principles of equality before the law is contained in Article 28D paragraph (1) of the 1945 Constitution, namely that everyone has the right to recognition, guarantees, protection, and fair legal certainty and equal treatment before the law. The right to legal aid is a human right. Where everyone involved in a case has the right to obtain legal assistance as stated in Article 37 of Law No. 4 of 2004 concerning Judicial Power. ${ }^{1}$

Legal Aid itself according to Law Number 16 of 2011 concerning Legal Aid is a legal service provided by Legal Aid Providers free of charge to Legal Aid Recipients. Legal Aid is a form of guarantee, protection, and legal certainty for everyone as a legal object to uphold justice and protect human rights. The legal aid is the responsibility of the state to provide access to justice for the poor in order to receive protection and equality before the law. The right to obtain legal assistance is a fundamental or basic right for someone who is in legal trouble. Because obtaining legal assistance is one form of access to justice for those who are or are dealing with legal problems. Obtaining legal assistance is also a manifestation of equality before the law.

The provision of legal aid is a means of supporting law enforcement in general and efforts to protect human rights from arbitrary actions by law enforcement officials. Law enforcement officers (criminal) are part of the structural components of criminal law, so that no matter how perfect the substance of criminal law without law enforcement, there is no benefit in realizing the goals of the criminal justice system. The Criminal Procedure Code (KUHAP) has appointed

1 Ajie Ramdan, "Bantuan Hukm Sebagai Kewajiban Negara untuk Memenuhi Hak Konstitusional Fakir Miskin”, Jurnal Konstitusi, Vol. 11, Nomor 2, Juni 2014 
and placed the suspect or defendant in a position of dignity, as a creature of God who has complete human dignity. The suspect or defendant has been placed in the Criminal Procedure Code in the position of his entity and dignity as a human being, which must be treated in accordance with noble human values. The law must be enforced, but in carrying out law enforcement against a suspect or defendant, the main human rights inherent in him must not be stripped. ${ }^{2}$

Legal aid or community organizations are intended to assist the poor in dealing with legal problems, because they can reduce the possibility of the poor not getting legal assistance to defend their legal interests both inside and outside the court and can help the poor to gain knowledge about law, human rights. human rights, civil and political rights, social rights, cultural rights and economic rights. This legal aid is given to the poor which can be obtained free of charge at no cost or called prodeo/pro bono publico). ${ }^{3}$ Because the poor are the responsibility of the state, the state is obliged to ensure that the rights of citizens are fulfilled, in this case the poor in obtaining equal rights before the law.

Every suspect or defendant has human rights such as equal rights and position and obligations before the law; Must be presumed innocent or presumption of innocence; Arrest or detention is based on sufficient preliminary evidence; The right to prepare a defense early. However, these rights can be infringed if law enforcers take action arbitrarily; kill (extrajudicial execution), arrest, detain, torture, search and arbitrarily confiscate the goods of a citizen. ${ }^{4}$ These practices deviate from the provisions in a rule of law, but can occur to defendants or suspects. This can happen because of the lack of knowledge of the suspect or defendant or because of the helplessness of the suspect or defendant.

In carrying out their duties in providing legal aid, legal aid providers can recruit lawyers, paralegals, lecturers, and law faculty students. The existence of this provision shows that the actors who will provide legal assistance are not only monopolies from advocates but paralegals, lecturers and law students can also provide legal assistance. Unfortunately, the Law on Legal Aid does not classify which areas are allowed for other than advocates to practice. This raises the ambiguity of the scope of the roles of each. The accommodation of paralegals, lecturers and law students as part of legal aid activities is a positive thing,

2 M. Yahya Harahap, Pembahasan Permasalahan dan Penerapan KUHAP Penyidikan dan Penuntutan, Jakarta: Sinar Grafika, 2009, pp. 1-2. See also Nabilla Banuati, "The Complicated Conditions on Indonesian Law Enforcement: A Book Review Kumpulan Catatan Hukum, Dr. Reda Manthovani SH LLM, Bhuana Ilmu Populer (Kelompok Gramedia), Jakarta, 2017, 234 pages, ISBN 978-602-394-6303.” JILS (Journal of Indonesian Legal Studies) Vol. 5 No.1, 2020, pp. 267-276.

3 Ihdi Karim Makinara, "Pengaruh Bantuan Hukum terhadap Masyarakat Miskin (Meninjau Undang-Undang Nomor 16 Tahun 2011 tentang Bantuan Hukum", Jurnal RechtsVinding Media Pembinaan Hukum Nasional, Vol. 2, No 1, April 2013

4 Ajie Ramdan, op.cit 
considering the limited number of advocates who are willing and committed to providing legal assistance, especially in remote areas. Their involvement can at least handle cases of people who have difficulty accessing legal aid, either because of limited lawyers or because they are in remote areas. Government regulations must be able to define the scope of each in providing legal aid, so that there will be no misuse and efforts to provide legal aid can still be carried out properly. ${ }^{5}$

However, the role of legal aid institutions has not been fully felt. The Law on Legal Aid currently only provides legal assistance to groups of poor people as evidenced by the existence of a Poor Certificate and the like (according to Article 14 paragraph (1) point c of Law 16/2011 concerning Legal Aid). While on the other hand, there is a need legal assistance is also from vulnerable groups such as children, women, indigenous peoples and persons with disabilities regardless of their economic conditions. In Articles 17 and 18 of Law Number 23 of 2002 concerning Child Protection, it is stated that every child who is deprived of his freedom or becomes a victim or perpetrator of a criminal act, has the right to get legal assistance. This is further strengthened in Article 23 paragraph (1) of Law Number 11 of 2012 concerning the Juvenile Criminal Justice System which states: "At every level of examination, children must be given legal assistance and accompanied by a Community Counselor or other assistant in accordance with the provisions of the legislation. " Then the right to legal aid for persons with disabilities is expressly regulated in Article 29 of Law no. 8 of 2016 concerning Persons with Disabilities, and specifically requires the Government and Regional Governments to provide legal assistance to Persons with Disabilities in every examination of every law enforcement agency in civil and/or criminal matters in accordance with the provisions of laws and regulations. ${ }^{6}$

In a study conducted by the Commission for Missing Persons and Victims of Violence (Kontras) from July 2020 to May 2021, it was noted that the most violent acts occurred, namely shootings as many as 390 times in handling criminal acts. Then there were 75 arbitrary arrests, 66 tortures, 58 forced disbandments, 36 tortures, 24 intimidation, 12 wrongful arrests, 6 inhumane acts, 3 sexual crimes, 2 murders, and 1 kidnapping. time. This cumulative shooting has left 13 people dead and 98 injured. At the Polres level, 250 shootings occurred out of 208 criminal acts. Then the Police who carried out 81 shootings from a total of 71 criminal acts. While at the Regional Police there were 59 shootings of 39 criminal acts. Such shootings must be in accordance with existing regulations. For example, in the case of the shooting of Deki Susanto,

5 Forum Akses Keadilan untuk Semua, Bantuan Hukum untuk Semua, Jakarta Selatan: Fokus, 2012.

6 Yayasan TIFA Lmbaga Bantuan Hukum Indonesia, Panduan Penyelenggaraan Bantuan Hukum di Daerah, Jakarta: Menkuham, 2018. 
who allegedly received extrajudicial killings by members of the South Solok Resort Police on Wednesday, January 27, 2021, at around 14.30 WIB, which resulted in death. Meanwhile, there are irregularities because there is no arrest warrant for the suspect or the suspect's family. Where the action was not in accordance with the procedure, because the victim did not fight back and the shooting was directed at the victim's head. This shows the arbitrariness of the legal apparatus without regard to human rights. $^{7}$

On the other hand, the Director General of Human Rights, Mualim Abdi, also explained that torture and violence were often carried out by prisons. This can happen because of the helplessness of the inmates both in detention and prisons. There have been no other actions such as other officers such as prosecutors, judges in which the suspect or defendant does not have the opportunity to defend himself in front of the court, no explanation has been given to the suspect or defendant regarding their rights. ${ }^{8}$ Therefore, the need for increasing the quantity and quality of legal aid services for the poor is quite large by providing protection to suspects or defendants from arbitrary actions by law enforcement officials. Even though every officer on duty has a code of ethics that must be obeyed and the existing rules, threats to the rights that are injured can occur at any time. So this is where the role of each legal aid institution is to take a role in legal protection, including advocates who are in the legal aid institution.

\section{LBH AND THE LEGAL AID ADVANCEMENT IN INDONESIA}

As a state of law (rechtsstaat) as stated in Article 1 paragraph (3) of the 1945 Constitution which states "The State of Indonesia is a state of law", the state must guarantee the equality of everyone before the law and protect human rights. Equality before the law means that everyone has the right to be treated equally before the law (equality before the law). The equality of treatment before the law applies to everyone regardless of their background, whether it is race, religion, descent, education or place of birth, in order to obtain justice through the judiciary.

7 Merdeka.com, "Kontras sebut Kasus Penembakan Paling Banyak dilakukan Polisi Selama Setahun”, Merdeka.com, 30 Juni 2021, diakses pada 9 Juli 2021 pukul 2.45 WIB di https://www.merdeka.com/peristiwa/kontras-sebut-kasus-penembakanpaling-banyak-dilakukan-polisi-selama-setahun.html

8 Kompas.com, "Kemenkumham ingatkan Petugas Tak Lakukan Kekerasan pada Warga Binaan”, kompas.com, 10 Maret 2021 diakses pada tanggal 9 Juli 2021 pukul 03.00 WIB https://nasional.kompas.com/read/2021/03/10/07413761/kemenkumham-ingatkanpetugas-tak-lakukan-kekerasan-pada-warga-binaan?page=all 
Everyone, who is suspected, arrested, detained, prosecuted and/or brought before a court, must be presumed innocent before a court decision declares his guilt and obtains permanent legal force as stated in Article 8 of Law no. 14 of 1970 concerning Judicial Power with the amendment of Law no. 35 of 1999 and further refined by Law. No. 4 of 2003. The implicit meaning of equality before the law can also be found in Article 37 and Article 38 of Law no. 14 of 1970 jo. UU no. 4 of 2003 concerning Judicial Power.

In Law no. 8 of 1981 concerning the Criminal Procedure Code both on the principle of equality of position before the law and the principle of presumption of innocence is not explicitly stated in one of the articles, but it is implied both in the preamble and general explanation of the Criminal Procedure Code, especially in point 3, among others, it is emphasized: "...the principles governing the protection of the nobility of human dignity which have been laid down in Law no. 14 of 1970 concerning the Basic Provisions of Judicial Power, must be enforced in and with this law". These principles include: ${ }^{9}$

a. Equal treatment of everyone before the law without making any difference in treatment. The form of equality of treatment before the law is that everyone has the right to obtain legal assistance and defense from advocates in accordance with the provisions of the law, so that not only people who can afford it can get help from advocates but also the poor or people who can't afford it, as well get the same rights in order to obtain justice (access to justice)

b. Everyone who is suspected, arrested, detained, indicted in court, must be presumed innocent until a court decision declares his guilt and obtains a presumption of innocence;

c. Everyone who is involved in a case must be given the opportunity to obtain legal assistance which is solely given to carry out the interests of defending himself.

Legal aid is the implementation of Article 1 paragraph (1) of the Criminal Code (KUHP) which reads: An act cannot be punished, except for what is commonly referred to as the principle of legality. The principle of legality itself is a general principle of universally applicable criminal law. Although it does not explicitly mention legal aid, Article 1 of the Criminal Code has the same substance and purpose, namely as a legal protection for the rights of freedom and body of a suspect or defendant. So it is appropriate if legal aid is seen as a tangible manifestation of the principle of legality.

9 Gatot Triyanto, "Persamaan Hak Bagi Tersangka atau Terdakwa untuk Memperoleh Bantuan Hukum Dalam Kitab Undangundang Hukum Acara Pidana (KUHAP)", Jurnal Rechtens, Vol 7, No 2, Desember 2018. See also Pristiwanto, B. (2013). Menjadikan Keteladanan Sebagai Roh Pendidikan Karakter di Akpol. Tanggon Kosala, 2(1), 1-14. 
Legal aid comes from the word "aid" which means help without expecting anything in return, and the word "law" which contains the overall meaning of the rules or norms regarding an aspect of community life with the intention of creating peace. ${ }^{10}$ Legal aid is an important instrument in the criminal justice system because it is part of the protection of human rights, especially the right to freedom and the right to body. However, the most basic of legal aid, is whether legal aid is mandatory or only required after certain conditions are met.

Based on the provisions of Article 56 paragraph (1) of the Criminal Procedure Code, that a person who is prosecuted for crimes punishable by a minimum prison sentence of 5 years must be assisted/accompanied by legal counsel, or other legal assistance from a Legal Aid Institute established by a Non-Governmental Organization. The right to be defended by an advocate and to obtain legal aid for the poor has existed for a long time as regulated in the Reglement op de rechtsvordering (Rv) for Europeans (Europeans) and HIR for Foreign Easterners (Vreemde Oosterlingen), but there is no similar guarantee for low-income groups. indigenous. ${ }^{11}$

Legal Aid is legal services provided by Legal Aid Providers free of charge to Legal Aid Recipients as contained in Article 1 point 1 of Law Number 16 of 2011 concerning Legal Aid. On the other hand, the legal aid referred to in the Criminal Procedure Code includes the provision of professional and formal legal aid services, in the form of providing legal aid services to everyone involved in criminal cases, either free of charge for those who are unable and poor or providing assistance to them. which advocates can afford by receiving compensation for services. ${ }^{12}$ namely: ${ }^{13}$

Schuyt, Groenendijk and Sloot distinguish legal aid into five types,

1. Preventive Legal Assistance, is legal assistance carried out in the form of providing legal information and counseling to the public so that they understand their rights and obligations as citizens.

2. Diagnostic Legal Aid, here legal assistance is carried out by giving legal advice or commonly known as legal consultation.

3. Legal Assistance for Conflict Control, this legal aid is more aimed at actively addressing concrete legal problems that occur in the community. This is usually done by providing legal assistance to members of the public who cannot afford to hire/use the services of an advocate to fight for their interests.

10 Adnan Buyung Nasution, Bantuan Hukum di Indonesia, Jakarta: LP3ES, 1988, pp. 4-5

11 Gatot Triyanto, Op.cit

12 Ajie Ramdan, Op.cit

13 Binziad Kadafi, et al., Advokat Indonesia Mencari Legitimasi Studi Tentang Tanggung Jawab Profesi Hukum di Indonesia, Jakarta: Pusat Studi Hukum dan Kebijakan Indonesia \& Asia Foundation, 2001, pp. 208-209 


\section{Syalis Mei Setiani}

4. Legal Aid for Legal Establishment; This legal aid is intended to provoke a more firm, precise, clear and correct jurisprudence.

5. Legal Aid for Legal Reform, is legal assistance whose efforts are more aimed at carrying out legal reforms, either through judges or through legislators.

Meanwhile, in Indonesia, there are two types of legal aid, namely individual and structural legal aid. Individual legal aid is the provision of legal assistance to people who are unable to assist in the form of assistance by advocates or lawyers in the dispute resolution process faced by advocates or lawyers in the process of resolving disputes faced, both before the court and through other dispute resolution mechanisms such as arbitration, in order to ensure equal distribution of legal services to all levels of society.

The provision of legal aid is very necessary to guarantee and realize equality before the law for everyone, especially the poor who are positioned as suspects or defendants. This is also intended to create the principle of "fair trial" where legal assistance carried out by an advocate in the context of the process of resolving a criminal case, both from the investigation stage and at the trial process, is very important to ensure the implementation of the legal process in accordance with the existing rules. , especially when advocates represent suspects or defendants in court proceedings to provide legal arguments to defend the interests of the suspect or defendant. In reality, not all suspects or defendants have the ability to use the services of an advocate to defend their interests in obtaining legal assistance and justice. This is because most of the community members. ${ }^{14}$

Based on the definition of legal aid, legal aid recipients must also know what rights and obligations will be provided by legal counsel according to law number 16 of 2011 concerning legal aid.

1. Recipients of legal aid are entitled

a. Obtain legal assistance until the legal problem is resolved and or the case has a permanent law, as long as the recipient of the legal aid concerned does not revoke the power of attorney.

b. Obtain legal assistance in accordance with legal aid standards and or in accordance with the Advocate's code of ethics.

c. Obtain information and documents related to the implementation of legal aid providers in accordance with the provisions of the legislation.

2. Recipients of mandatory legal aid

a. Submit evidence, information, and/or case information correctly to legal aid providers

14 Gatot Triyanto, Op.cit 
b. Helping the smooth running of legal aid providers. ${ }^{15}$

Recipients of legal aid are any poor person or group of people who cannot fulfill their basic rights properly and independently. In addition, legal aid recipients can also come from: ${ }^{16}$

1) child;

2) persons with disabilities;

3) women;

4) elderly population;

5) Indonesian workers; or

6) other vulnerable people or groups in accordance with their regional context and regulated in laws and regulations.

The provisions of Article 56 paragraph (1) of Law Number 8 of 1981 concerning the Criminal Procedure Code (KUHAP) as a provision with human rights values have been appointed as one of the benchmarks for the Miranda Rule or the Miranda Principle. Miranda Rule is a rule that is universal in almost all countries which by law have similar legal regulations. The state of Indonesia, which is a state of law, highly respects the miranda rule, as evidenced by adopting the miranda rule in the Criminal Procedure Law system, namely in Article 56 paragraph (1) of Law no. 8 of 1981 KUHAP. Where in Article 56 Paragraphs (1) and (2) of the Criminal Procedure Code there are special requirements concerning: (a) ability (financial); and (b) the threat of punishment for the alleged crime. If the mandatory provisions required in Article 56 paragraph (2) of the Criminal Procedure Code are ignored, it will lead to legal consequences, namely the public prosecutor's demands are declared unacceptable or result in the investigation conducted by the investigator (BAP) being invalid. Where if the requirements of the request and or the rights of the suspect/defendant are not fulfilled, such as the investigator does not appoint legal counsel for the suspect/defendant since the beginning of the investigation, the demands of the public prosecutor cannot be accepted. Thus, according to Article 56 paragraph (1), the Criminal Procedure Code guarantees for criminal cases with the threat of the death penalty or a sentence of more than 15 years or the threat of a sentence of more than 5 years for those who are unable and legally blind, the state through the official concerned at all levels of examination in the judicial process are required to appoint legal advisers (advocates). ${ }^{17}$

Likewise for suspects or defendants who are materially threatened with a criminal "under 5 (five) years", from the time of the examination/investigation until the trial before the court, the suspect or defendant who is incapable (poor) is not given the right to obtain legal

15 Henry Dermawan, "Hak dan Kewajiban Advokat menurut Undang-Undang Nomor 16 Tahun 2011 tentang Bantuan Hukum”, Lex et Societatis, Vol. IV, No. 2, Februari 2016

16 Yayasan TIFA Lembaga Bantuan Hukum Indonesia, Op.cit

17 Gatot Triyanto, Op.cit 
assistance from advocate to defend their rights. As a result, prosecutors as public prosecutors and judges often treat suspects or defendants arbitrarily and place the defendant's position as an object rather than a subject, sometimes judges become prosecutors during examinations before trial, and even over-act by not being objective. but continues to accuse the defendant of being the perpetrator of a crime without giving the defendant the opportunity to defend himself. Against a suspect or defendant who commits a criminal act which is threatened with a sentence of less than 5 (five) years, in principle the right to legal assistance has been recognized, but it is not included in the rights that are "mandatory" in the sense that they are still "rights". , has not yet reached the level that is required or is mandatory. ${ }^{18}$

If viewed from the system/work pattern for the implementation of Legal Aid, Legal Aid is included in the characteristics of the absolute authority of the central government. This is reinforced that the implementation of legal assistance is carried out by the Central Government (Ministry of Law and Human Rights cq BPHN) or delegated authority to Vertical Agencies in the Region (Regional Office of the Ministry of Law and Human Rights) or the governor as a representative Central Government based on the principle of Deconcentration. In carrying out its function of providing legal aid, the Central Government (Minister) has the following duties:

a. formulate and stipulate policies for the implementation of Legal Aid;

b. compiling and establishing Legal Aid Standards based on the principles of providing Legal Aid;

c. prepare a legal aid budget plan;

d. manage the Legal Aid budget in an effective, efficient, transparent and accountable manner; and

e. prepares and submits a report on the implementation of Legal Aid to the House of Representatives at the end of each fiscal year and has the authority to include:

1) supervise and ensure the implementation of Legal Aid and the provision of Legal Aid

2) carry out verification and accreditation of legal aid institutions or community organizations to meet eligibility as Legal Aid Providers. ${ }^{19}$

The Law on Legal Aid defines Legal Aid Providers as legal aid institutions or community organizations that provide legal aid services (article 1 number 3). Based on these provisions, the provision of legal aid to the community cannot be attached to the functions and roles of an organization, whether it is an organization. To become a legal aid provider there are several conditions that must be met, namely; (a) is a legal entity; (b) accredited under this law; (c) have a permanent office or

18 Ibid.

19 Yayasan TIFA Lembaga Bantuan Hukum Indonesia, Op.cit 
secretariat; (d) have administrators; and (e) have a Legal Aid program. In carrying out their duties in providing legal aid, the legal aid provider has the right to (article 9):

a. recruiting advocates, paralegals, lecturers, and law faculty students;

b. perform Legal Aid services;

c. organize legal counseling, legal consultation, and other program activities related to the implementation of Legal Aid;

d. receive a budget from the state to implement Legal Aid based on this Law;

e. issue an opinion or statement in defense of a case for which it is responsible in a court session in accordance with the provisions of the legislation;

f. obtain information and other data from the government or other agencies, for the purpose of case defense; and

g. get guaranteed legal protection, security, and safety while carrying out the provision of Legal Aid.

In addition to authority, Legal Aid Providers also have obligations, which are contained in Article 10, which include the following;

a. report to the Minister about the Legal Aid program;

b. report every use of the state budget used for the provision of legal aid based on this Law;

c. organize legal aid education and training for lawyers, paralegals, lecturers, law faculty students who are recruited as referred to in Article 9 letter a;

d. maintain the confidentiality of data, information, and/or information obtained from Legal Aid Recipients in relation to the case being handled, unless otherwise stipulated by law; and

e. provide legal assistance to Legal Aid Recipients based on the terms and procedures specified in this Law until the case is completed, unless there is a legally valid reason.

Government regulations need to regulate more clearly about legal aid providers whose legal entity status does not stand alone, but is attached to being part of the parent organization such as LKBH for Higher Education, LBH for labor organizations, and LBH for mass organizations. LBH under the auspices of a political party should not have access to legal aid funds, because a party is an entity that has certain interests in accordance with the ideology of the party.

Government regulations need to clarify whether the term 'legal entity' is only an organization registered in the law and human rights department, or it can also include organizations registered in other agencies, given that there are several legal aid organizations whose parent is registered in another agency, not the legal department and HAM. Government regulations do not need to limit that only lawyers can provide legal assistance. This restriction is contrary to the legal aid law itself, in which there are also groups other than advocates who can 
provide legal aid. On the other hand, Government Regulations need to regulate in more detail the scope of legal aid work carried out by advocates, lecturers, paralegals, and students. Confirmation in the PP is needed so that there is no overlap, and becomes a reference for law enforcement officials to allow them to provide legal assistance according to its scope. Government regulations need to regulate the complaint mechanism as a means for people seeking justice to obtain the best legal aid services from legal aid providers. In fact, there are "impromptu" legal aid organizations that were formed just to get legal aid funds. ${ }^{20}$

Legal Aid Providers in legal aid institutions may consist of advocates, paralegals, lecturers, and law faculty students. Advocates play an important role in providing legal assistance as stipulated in Law no. 18 of 2003 which states that legal aid providers are advocates, and in Chapter VII concerning Legal Aid, Law no. 8 of 1981 concerning the Criminal Procedure Code states that the legal aid provider is a legal advisor. According to article 69 of the law on criminal procedural law, it is explained that legal counsel has the right to contact the suspect from the moment he is arrested or detained at all levels of examination according to the procedure specified in the law. In article 22 paragraph (1) of Law no. 18 of 2003 concerning Advocates states that, Advocates are obliged to provide free legal assistance to justice seekers who cannot afford.

For defense, the advocate has the right to send and receive letters from the suspect whenever he wishes. In accordance with the level of examination for dealing with suspects, advocates are supervised by investigators, public prosecutors or correctional officers without being heard of the contents of their conversation. In providing legal aid by this advocate, it aims to enforce the rules and provide a sense of justice for suspected perpetrators of criminal acts in participating in criminal proceedings. The existence of an advocate is also intended so that if the suspect in the criminal act is proven guilty, the punishment in the form of a court decision has justice for the suspect. The purpose of sentencing is to establish the welfare of the State and Society which does not conflict with the norms of decency and humanity.

Article 12 paragraph 1 Government Regulation no. 83 of 2008 concerning the Requirements and Procedures for the Provision of Free Legal Aid further also emphasizes that, Advocates are prohibited from refusing applications for free legal aid. Based on the Indonesian Advocates Association Regulation No. 1 of 2010 concerning the Implementation Guidelines for the Provision of Free Legal Aid which applies to advocate organizations states that PERADI Advocates are recommended to provide free legal aid of 50 hours/year. These provisions have clearly shown that advocates are obligated to provide

20 Forum Akses Keadilan untuk Semua, "Bantuan Hukum untuk Semua", Jakarta Selatan: Fokus, 2012 
legal assistance to any person or group of suspects who commit a criminal act to assist them at every level of examination. ${ }^{21}$ This is also spelled out in the code of ethics for advocates that advocates have an obligation to provide free legal aid for people who can't afford it (Article $7 \mathrm{~h}){ }^{22}$

The position of advocates as law enforcers has been regulated in Article 5 of Law No.18 2003 concerning Advocates which reads:

1) Advocates have the status of law enforcers, free and independent guaranteed by laws and regulations.

2) The working area of an Advocate covers the entire territory of the Republic of Indonesia.

Regarding the requirements that must be met, it is contained in Article 2 paragraph 1 which reads "Those who can be appointed as advocates are graduates with a higher education background in Law and after attending special education for the advocate profession carried out by the Advocates Organization." The other conditions are contained in Article 3 paragraph 1:

a. Citizen of the Republic of Indonesia.

b. Domiciled in Indonesia.

c. Not status as a civil servant or state official.

d. At least 25 (twenty five) years old.

e. Holds a bachelor's degree with a higher education background in law.

f. Pass the exam held by the Advocates Organization.

g. Internship for at least 2 (two) years continuously at an advocate's office

h. Never been convicted of a crime of imprisonment of 5 (five) years or more.

i. Behave well, be honest, responsible, fair, and have high integrity.

As for the duties and responsibilities of an advocate as confirmed by Law No. 18 of 2003 in handling a case:

1) Uphold the professional code of ethics

2) Guiding and protecting clients from worldly and hereafter disasters in order to find truth and justice that satisfies all parties, in accordance with legal, moral and religious values.

3 ) Assist in the creation of a simple, fast and low-cost judicial process, as well as the achievement of a final case dispute resolution.

4) Respect the judiciary and the judicial process in accordance with legal, religious and moral norms

5) Protecting clients from the oppression of other parties and protecting them from doing wrong to other parties

21 Dewa Gede Tedy Sukadana, "Keabsahan Pemberian Bantuan Hukum terhadap Tersangka yang Melakukan Tindak Pidana di Daerah Bali”, Kertha Wicara: Jurnal Ilmu Hukum, Vol 05, No. 06, November 2016

22 Ibid. 
6) Holding fast to the trust given to his client with full responsibility both to his client, himself, law and morals, as well as to God Almighty

7) Provide periodic reports and explanations to clients regarding the tasks entrusted to them

8) Avoiding various forms of covert blackmail against clients

9) Be sympathetic and feel what the client is suffering and even prioritize the interests of his clients over his personal interests

10) Between a legal attorney or an advocate and his client, a trusting and trustworthy relationship must be established so that there is no mutual harm and loss

11) Carry out professional duties as a legal service provider, act honestly, fairly, and responsibly based on law and justice

12) Advocates are also obliged to provide legal assistance free of charge for clients who cannot afford it, this is in accordance with the decision of the Supreme Court No. 5/KMA/1972 concerning groups that are obliged to provide legal assistance.

In the Advocate's Code of Ethics, instructions have also been given to its members regarding the following matters:

a. About responsibility

b. About what they have to do.

c. Maintain behavior/behavior as a professional in carrying out his profession

d. Integrity must be maintained in carrying out his profession

e. Maintain reputation

In the Law on Advocates, it is explained that an advocate has the status of a law enforcer, free and independent which is guaranteed by law and statutory regulations. The provisions of Article 5 Paragraph (1) of the Advocate Law give status to Advocates as law enforcers who have an equal position with other law enforcers in upholding law and justice. This position requires an organization which is the only forum for the Advocate profession as referred to in Article 28 Paragraph (1) of the Advocates Law, namely the Advocates Organization is the only free and independent Advocate professional forum established in accordance with the provisions of this Law with the aim of and the aim is to improve the quality of the Advocate profession. Therefore, the Advocates Organization, namely PERADI, is basically a state organ in a broad sense that is independent (independent state organ) which also carries out state functions. ${ }^{23}$

23 Riska Natalia Polii, "Bantuan Hukum oleh Advokat Dalam Proses Pengajuan Gugatan Perdata dalam Kaitannya dengan Penegakan Hukum Perdata Materil”, Lex Privatum, Vol VI, No 6, Agustus 2018. See also Cahya Wulandari, Sonny Saptoajie Wicaksono, and Umi Faridatul Khikmah. "Paralegal Existence in Providing Access to Justice for the Poor in Central Java." IJCLS (Indonesian Journal of Criminal Law Studies) Vol. 4 No.2, 2019, pp. 199-206. 
The role that a defender plays is that of a guardian (guard) of power court. In this case, the defender has the duty to ensure that legal officials do not commit frauds so as to harm the rights of the suspect/defendant. ${ }^{24}$ The Paralegal skills are having basic knowledge in the fields of law and human rights, as well as organizational skills, negotiation, communication, research, and other skills. ${ }^{25}$ Skills in synthesizing chronological cases covering $5 w 1 h$ supported by facts, grammar, and coherence.

According to Article 69 of Law Number 8 of 1981 concerning the Criminal Procedure Code, it is stated: Legal advisers have the right to contact suspects from the time they are arrested or detained at all levels of examination according to the procedures stipulated in this law.

Article 70 states in the paragraph:

(1) The legal advisor as referred to in Article 69 has the right to contact and talk to the suspect at every level of examination and at any time for the purpose of defending his case.

(2) If there is evidence that the legal adviser has abused his rights in the discussion with the suspect, according to the level of examination, the investigator, public prosecutor or correctional officer will give a warning to the legal adviser.

(3) If the warning is not heeded, then the relationship is supervised by the official referred to in paragraph (2).

(4) If after being supervised, his rights are still being abused, then the relationship is witnessed by the official referred to in paragraph (2) and if after that it is still violated then the further relationship is prohibited.

Law Number 8 of 1981 concerning Criminal Procedure Code, Article 71 states in paragraph:

(1) Legal advisers, according to the level of examination, in dealing with suspects are supervised by investigators, public prosecutors or correctional officers without hearing the contents of the conversation.

(2) In the case of a crime against state security, the official referred to in paragraph (1) can hear the contents of the conversation.

Article 72 which reads: At the request of the suspect or his legal adviser, the official concerned shall provide a derivative of the examination report for the benefit of his defense. Legal advisers have the right to send and receive letters and suspects whenever they wish as

24 Ibid.

25 Rifqi Ridlo Phahlev, et.al., Modul Pelatihan Paralegal, (idoarjo: UMSIDA Press, 2021, pp. 76-77 


\section{Syalis Mei Setiani}

referred to in Article 73, as well as Article 74, namely Reduction of the freedom of relations between legal counsel and suspects as referred to in Article 70 paragraph (2), paragraph (3), paragraph (4) and Article 71 is prohibited, after the case has been delegated by the public prosecutor to the district court for trial, a copy of the letter is submitted to the suspect or his legal adviser and other parties in the process.

So, legal protection is a legal act that has a balance of justice given in a balanced and impartial proportion. Therefore, legal protection is held or provided as a joint effort based on the relevant principles, namely:

a. Legality Principle

The existence of a special body to make good and democratic regulations and laws, according to the aspirations of the people or citizens. Therefore, by making laws and regulations, they can be used as barometers or guidelines to be obeyed;

b. Protection principle

With an effort to be able to give a special position to someone as a human right in the implementation and enforcement of good and right laws, in its implementation it is hoped that the implementing apparatus can guarantee human rights and obligations. selfish;

c. Principle of Legal Certainty

That the rule of law is made to be enforceable is enforced by the state and society. The law exists because of concrete events. So legal certainty is a judicial protection against arbitrary actions, meaning that someone will get something given under certain circumstances. The community expects legal certainty, so that the objectives will be created, namely, public order and can guarantee legal certainty;

d. Principles of Justice

The community is very concerned that in the implementation or enforcement of the law justice is considered. In the implementation or enforcement of the law, it must be fair, so that the law is identical with justice. The law is to bind everyone, is generalizing. On the other hand, justice is subjective, individualistic and generalizing. ${ }^{26}$

Law Number 16 of 2011 concerning Legal Aid, regulates the Terms and Procedures for Providing Legal Aid, in Article 14 it is stated in the paragraph:

(1) To obtain Legal Aid, a Legal Aid applicant must meet the following requirements:

a. submit a written application containing at least the identity of the applicant and a brief description of the subject matter for which Legal Aid is being applied for;

b. submit documents relating to the case; and

26 Janesande Palilingan, "Hak dan Kewajiban Penerima Bantuan Hukum Ditinjau dari Aspek Hak Asasi Manusia”, Lex Administratum, Vol. III/No. 7/Sep/2015. 
c. attach a certificate of poverty from the lurah, village head, or an official at the same level as the place of residence of the legal aid applicant.

(2) In the event that the Legal Aid applicant is unable to prepare a written application, the application may be submitted orally.

Article 15 paragraph:

(1) Applicants for Legal Aid shall apply for Legal Aid to the Legal Aid Provider.

(2) Legal Aid Providers within a period of no later than 3 (three) working days after the application for Legal Aid is declared complete must provide an answer to accept or reject the application for Legal Aid.

(3) In the event that the application for Legal Aid is received, the Legal Aid Provider shall provide Legal Aid based on a special power of attorney from the Legal Aid Recipient.

(4) In the event that the application for Legal Aid is rejected, the Legal Aid Provider shall state the reasons for the refusal.

(5) Further provisions regarding the terms and procedures for providing Legal Aid are regulated by a Government Regulation.

Giving legal aid is a noble profession, whether it is done by advocates, paralegals, lecturers, or students. But in the service of men with more demands, namely on advocates in carrying out their duties to provide legal services. Especially for poor people who have limited funds to solve existing legal problems, they really hope for full assistance from legal aid providers. The central government and regional governments are also obliged to seek assistance through the funds budgeted in the State Revenue and Expenditure Budget and the Regional Revenue and Expenditure Budget as well as legal aid funding sources that can come from grants or donations, and/or other legal and non-binding funding sources. This is very much needed to facilitate the role of legal aid institutions to provide legal assistance. All related roles regarding legal aid are very important to be involved in the success of legal protection and equality before the law. So it is appropriate for every part of the profession, institution, government to carry out its roles and responsibilities as per the existing regulations and their code of ethics.

\section{CONCLUSION}

Legal Aid is closely related to Human Rights which is an inseparable part of the rule of law. The legal aid is a form of legal protection and the granting of rights to equality before the law. For this reason, Legal Aid Institutions play an important role in serving justice seekers so that they are not treated arbitrarily. Aid agencies themselves can recruit from advocates, paralegals, lecturers, law students, etc. However, the role that 
is most involved in providing legal aid is an advocate where in the code of ethics advocates are required to assist in the service of judge assistance. As in the Indonesian Advocates Association Regulation No. 1 of 2010 concerning the Implementation Guidelines for the Provision of Free Legal Aid applicable to advocate organizations states that PERADI Advocates are recommended to provide free legal aid of 50 hours/year Advocates themselves can assist both outside the trial and in the trial starting from from arrest to trial. This authority is greater than others such as lecturers and law students who are recruited in legal aid institutions. But of course all roles are very important, including the central and local governments in funding legal aid institutions in Indonesia because of the provision of free legal aid to the poor. So, the state must pay for it.

\section{REFERENCES}

Banuati, N. (2020). The Complicated Conditions on Indonesian Law Enforcement: A Book Review Kumpulan Catatan Hukum, Dr. Reda Manthovani SH LLM, Bhuana Ilmu Populer (Kelompok Gramedia), Jakarta, 2017, 234 pages, ISBN 978-602-394-6303. JILS (Journal of Indonesian Legal Studies), 5(1), 267-276.

Dermawan, H. (2016). Hak dan Kewajiban Advokat menurut UndangUndang Nomor 16 Tahun 2011 tentang Bantuan Hukum. Lex et Societatis, 4(2).

Forum Akses Keadilan untuk Semua. (2012). Bantuan Hukum untuk Semua. Jakarta Selatan: Fokus

Harahap, M. Y. (2009). Pembahasan Permasalahan dan Penerapan KUHAP Penyidikan dan Penuntutan. Jakarta: Sinar Grafika

Kadafi, B., et.al. (2001). Advokat Indonesia Mencari Legitimasi Studi Tentang Tanggung Jawab Profesi Hukum di Indonesia. Jakarta: Pusat Studi Hukum dan Kebijakan Indonesia \& Asia Foundation.

Kambey, F. F. (2013). Larangan dan Sanksi Pidana Bagi Pemberi Bantuan Hukum. Lex Crimen, 2(4).

Kompas.com. (2021). "Kemenkumham ingatkan Petugas Tak Lakukan Kekerasan pada Warga Binaan". kompas.com. 10 Maret 2021 diakses pada tanggal 9 Juli 2021 pukul 03.00 WIB di https://nasional.kompas.com/read/2021/03/10/07413761/kemenku mham-ingatkan-petugas-tak-lakukan-kekerasan-pada-wargabinaan?page $=$ all

Makinara, I. K. (2013). Pengaruh Bantuan Hukum terhadap Masyarakat Miskin (Meninjau Undang-Undang Nomor 16 Tahun 2011 tentang Bantuan Hukum. Jurnal RechtsVinding Media Pembinaan Hukum Nasional, 2(1).

Merdeka.com. (2021). "Kontras sebut Kasus Penembakan Paling Banyak dilakukan Polisi Selama Setahun”. Merdeka.com. 30 Juni 2021, 
diakses pada 9 Juli 2021 pukul 2.45 WIB di https://www.merdeka.com/peristiwa/kontras-sebut-kasuspenembakan-paling-banyak-dilakukan-polisi-selama-setahun.html Nasution, A. B. (1988). Bantuan Hukum di Indonesia. Jakarta: LP3ES

Palilingan, J. (2015). Hak dan Kewajiban Penerima Bantuan Hukum Ditinjau dari Aspek Hak Asasi Manusia. Lex Administratum, 3(7)

Phahlevy, R. R., et.al. (2021). Modul Pelatihan Paralegal. Sidoarjo: UMSIDA Press

Polii, R. N. (2018). Bantuan Hukum oleh Advokat Dalam Proses Pengajuan Gugatan Perdata dalam Kaitannya dengan Penegakan Hukum Perdata Materil. Lex Privatum, 6(6).

Pristiwanto, B. (2013). Menjadikan Keteladanan Sebagai Roh Pendidikan Karakter di Akpol. Tanggon Kosala, 2(1), 1-14.

Ramdan, A. (2014). Bantuan Hukm Sebagai Kewajiban Negara untuk Memenuhi Hak Konstitusional Fakir Miskin. Jurnal Konstitusi, 11(2).

Sukadana, D. G. T. (2016). Keabsahan Pemberian Bantuan Hukum terhadap Tersangka yang Melakukan Tindak Pidana di Daerah Bali. Kertha Wicara: Jurnal Ilmu Hukum, 5(6).

Triyanto, G. 2018. Persamaan Hak Bagi Tersangka atau Terdakwa untuk Memperoleh Bantuan Hukum Dalam Kitab Undangundang Hukum Acara Pidana (KUHAP). Jurnal Rechtens, 7(2).

Wulandari, C., Wicaksono, S. S., \& Khikmah, U. F. (2019). Paralegal Existence in Providing Access to Justice for the Poor in Central Java. IJCLS (Indonesian Journal of Criminal Law Studies), 4(2), 199-206.

Yayasan TIFA Lmbaga Bantuan Hukum Indonesia. (2018). Panduan Penyelenggaraan Bantuan Hukum di Daerah. Jakarta: Menkuham. 


\section{Legal aid is central to righting wrongs and rectifying injustice. \\ Sadiq Khan}

\section{Conflicting Interest Statement}

All authors declared that there is no potential conflict of interest on publishing this article.

\section{Funding}

None

\section{Publishing Ethical and Originality Statement}

All authors declared that this work is original and has never been published in any form and in any media, nor is it under consideration for publication in any journal, and all sources cited in this work refer to the basic standards of scientific citation.

Cite this article as:

Setiani, S. M. (2021). The Role of Legal Aid Institutions in Providing Legal Aid for Suspects and Defendants. The Indonesian Journal of International Clinical Legal Education, 3(4), 425-444. https://doi.org/10.15294/ijicle.v3i4.48297 